\title{
Purification and Characterization of $\beta-1,3-$ Glucanase from the Secretion of Simira glaziovii Colleters (Rubiaceae)
}

\author{
Felipe Almeida Vieira ${ }^{1}$, Maura da Cunha $^{2}$, Denise Espellet Klein ${ }^{2}$, André de Oliveira \\ Carvalho $^{1}$ and Valdirene Moreira Gomes ${ }^{1 *}$ \\ ${ }^{1}$ Laboratório de fisiologia e Bioquímica de Microrganismos; ${ }^{2}$ Laboratório de Biologia Celular e Tecidual; Centro \\ de Biologia e Biotecnologia; Universidade Estadual Norte Fluminense Darcy Ribeiro; Rua Alberto Lamego, 2000; \\ Horto; 28015-620; valmg@uenf.br; Campos de Goytacazes - RJ - Brasil
}

\begin{abstract}
In this study, $\beta$-1,3-glucanase was isolated from Simira glaziovii secretion. The purification process was achieved by a combination of chromatographic methods and was analyzed by SDS-PAGE. The purified enzyme presented an estimated molecular mass of $35 \mathrm{kDa}$. The optimum $\mathrm{pH}$ of enzyme was 5.2
\end{abstract}

Key words: $\beta$-1,3-glucanase, PR protein, chitinases, secretory structure

\section{INTRODUCTION}

Although plants are naturally exposed to several phytopathogenic microorganisms, they present tolerance to these pathogens, due to their different structures (cuticles, trichomes, stomata and tyloses) and biochemical mechanisms (such as phenols, phytoalexins, cyanogenic glycosides, protease inhibitors and hydrolases) (Pascholati and Leite, 1994; Oliveira et al., 2003; Caramori et al., 2004). Previous studies have reported that PR proteins are implied in the defense of the plant against viral, bacterial and fungal phytopathogens (Pegg and Young, 1981; Young and Pegg, 1982; Boller, 1987; Boller and Mêtraux 1988; Yun et al., 1987); the PR proteins from families 2 and 3 are $\beta$-1,3-glucanases and chitinases, respectively. Regard hydrolytic enzymes, it has also been reported that these increased in concentration in some plants infected by fungi, such as tomato (Pegg, 1977), tobacco (Kauffmam et al., 1987;
Legrand et al., 1987), potato (Kombrick et al., 1988), cucumber (Boller and Metraux, 1988) and beans (Vôgeli et al., 1988; Mauch and Staechelin, 1989). These proteins have been implicated in the resistance mechanisms of plants against pathogens and insects (Gomes et al., 1994).

Chitinases and $\beta$-1,3-glucanases are lytic enzymes capable of inhibiting fungi development by degrading the pathogen cell wall, which is mostly composed of chitin and $\beta-1,3$-glucans. These enzymes act synergistically inhibiting the growth of fungi. $\beta-1,3$-glucans and chitin are the two principal components of the cell wall of fungal pathogen (Mauch et al., 1988; Molano et al., 1979; Alexopoulos et al., 1996). The action of these enzymes also releases fragments from the cell wall, as elicitors for the production of phytoalexin (Darvill and Albershiem, 1984; Kauffmam et al., 1987). It has been suggested that $\beta-1,3$-glucanase is important for diverse physiological processes, for instance pollen development, stress response,

\footnotetext{
${ }^{*}$ Author for correspondence
} 
flowering and mobilization of store reserves and is critical in triggering seed germination (VogeliLange et al., 1994). Most secretory structures from plants appear to be related to the defense against some pathogens and insects (Chye and Cheung, 1995, Klein et al., 2004). In this study, the secretion of the Simira glaziovii colleter (Fig. 1), was isolated and characterized a $\beta-1,3$-glucanase, in order to understand the mechanisms of defense of the plants present in secretion structures.

\section{MATERIALS AND METHODS}

\section{Plant materials}

Shoot apex from Simira glaziovii (K. Schum.) Steyerm, were collected in the Atlantic rain forest of Barrage of Saracuruna, Duque de Caxias, RJ.

\section{Scanning electron microscopy}

Stipules were fixed for two hours in $2.5 \%$ Glutaraldehyde, $4.0 \%$ paraformaldehyde buffered with $50 \mathrm{mmol} \mathrm{L}^{-1}$ cacodylate buffer, $\mathrm{pH}$ 7.2. Subsequently the material was post-fixed for two hours at room temperature with $1.0 \%$ osmium tetroxide in $50 \mathrm{mmol} \mathrm{L}^{-1}$ cacodylate buffer, $\mathrm{pH}$ 7.2. The post-fixed material was dehydrated in a graded series of acetone solutions, critical point dried in $\mathrm{CO}_{2}$, covered with $20 \mathrm{~nm}$ gold and observed with a ZEISS 962 digital scanning electron microscope.

\section{Protein determination}

Total protein was quantified using protein micro assays based on the Bradford assay (1976).

\section{$\beta-1,3-g l u c a n a s e$ enzyme activity}

The determination of the $\beta-1,3$-glucanase activity in secretion samples was made according to the methodology described by Fink et al., (1988). The reaction mixture was composed of $50 \mu \mathrm{L}$ of the secretion sample, $125 \mu \mathrm{L}$ laminarin $\left(2 \mathrm{mg} \mathrm{mL}^{-1}\right.$ in Buffer sodium acetate $50 \mathrm{mmol} \mathrm{L}^{-1}, \mathrm{pH} \mathrm{5.0)}$ and mixed to a final volume of $500 \mu \mathrm{L}$ in a buffer of sodium acetate $50 \mathrm{mmol} \mathrm{L}^{-1}, \mathrm{pH} 5.0$. The reaction was incubated at $37^{\circ} \mathrm{C}$ for $12 \mathrm{~h}$. After the incubation period, $500 \mu \mathrm{L}$ of the copper reagent and this mixture was warmed to $100^{\circ} \mathrm{C}$ for 10 min. The mixture was left to return to room temperature and $500 \mu \mathrm{L}$ of arsen-molybdate solution were then added. Samples were read at $500 \mathrm{~nm}$ on a Shimadzu spectrophotometer. One unit of glucanase activity was defined as the concentration of the enzyme that provided an absorbance of 0.001 at $500 \mathrm{~nm}$

\section{Detection of peroxidase activity}

Peroxidase activity was determined by spectrophotometry at $470 \mathrm{~nm}$ (Leon et al., 2002). The reaction mixture consisted of $0.53 \%(\mathrm{v} / \mathrm{v})$ guaiacol and $0.042 \%(\mathrm{v} / \mathrm{v}) \mathrm{H}_{2} \mathrm{O}_{2}$ diluted in 100 mmol L ${ }^{-1}$ citrate-phosphate buffer, $\mathrm{pH}$ 5.5. The reaction mixture was added to a final volume of 3 $\mathrm{mL}$. The activity unit (a.u.) was defined as 0.01 absorbance increase in reaction mixture per $3 \mathrm{~min}$ $/ \mu \mathrm{g}$ protein.

\section{Detection of chitinase activity}

Chitinase activity was determined by the fluorescence released by the cleavage of the fluorogenic substrate, 4-methylumbelliferyl- $\beta$ - $D$ N, N', N"-triacetylchitotrioside (Sigma Chemical Co.) (O'Brien and Colwell, 1987). The standard reaction was performed by incubating $0.25 \mathrm{mmol}$ $\mathrm{L}^{-1}$ substrate with $50 \mu \mathrm{L}$ of sample $\left(0.1 \mathrm{mg} \mathrm{mL}^{-1}\right)$ in $2 \mathrm{~mL}$ of $50 \mathrm{mmol} \mathrm{L}^{-1}$ acetate buffer (pH 4.0) and the liberated methylumbelliferyl (MU) was measured fluorimetrically employing $320 \mathrm{~nm}$ primary and $460 \mathrm{~nm}$ secondary filters in a Hitachi F4500 fluorescence spectrophotometer. In order to relate fluorescence output to the concentration of released product a calibration curve was constructed using 4MU-sodium salts. One unit of enzyme activity corresponded to one nmol methylumbeliferone liberated per min.

\section{Enzyme extraction}

At the apexes, stipules were isolated and their secretion was recovered. Secretion was extracted by immersing stipules in $0.1 \mathrm{~mol} \mathrm{~L}^{-1}$ Tris- $\mathrm{HCl}, \mathrm{pH}$ 8.0 buffer and $0.1 \%$ Triton $\mathrm{X}-100$ for a few minutes. The material extracted was filtered and submitted to precipitation with ammonium sulfate to $90 \%$ saturation (F/0-90). After precipitation for $16 \mathrm{~h}$, the material was centrifuged at $10000 \mathrm{x} \mathrm{g}$ for 30 minutes at $40^{\circ} \mathrm{C}$, the supernatant was discarded and the precipitate was solubilized in distilled water and dialyzed in presence of water at $4^{\circ} \mathrm{C}$ for $48 \mathrm{~h}$. 


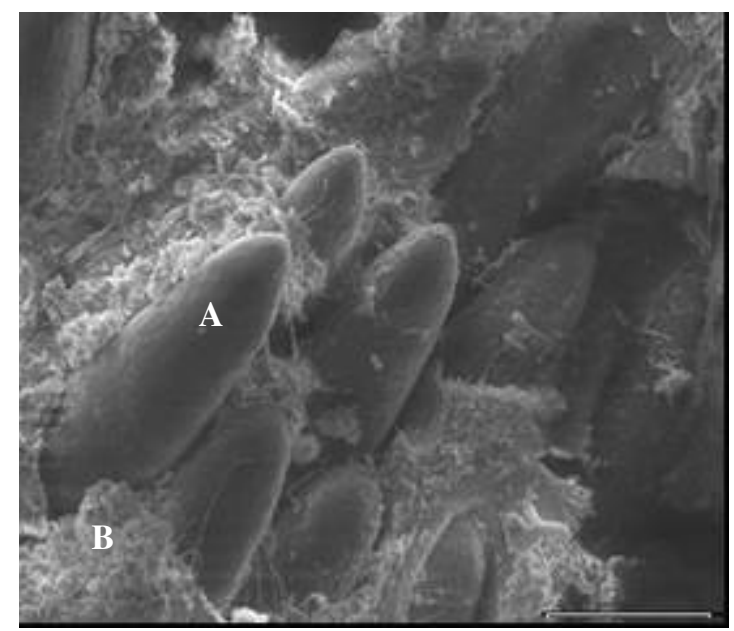

Figure 1- Simira glaziovii colleters, showing numerous colleters and secretion (100 X). A - colleter; B- secretion.

\section{Enzyme purification}

For $\beta$-1,3-glucanase purification, a DEAESepharose column $(2.5 \times 25 \mathrm{~cm})$ equilibrated with $100 \mathrm{mmol} \mathrm{L}^{-1}$ Tris-HCl (pH 8.0) was employed for separation of proteins from the F/0-90 fraction. Elution was initially achieved by the equilibrium buffer, when we obtained fraction D1. Bound proteins (D2) were eluted with $1 \mathrm{~mol} \mathrm{~L}^{-1} \mathrm{NaCl}$ in the same buffer. D1 fraction (which shows high enzyme activity) was pooled and submitted to one cycle of gel filtration chromatography in Sephcryl $\mathrm{S}-100$ (column of $2.3 \times 60.5 \mathrm{~cm}$ ) equilibrated and developed in $50 \mathrm{mmol} \mathrm{L}^{-1}$ acetate buffer ( $\mathrm{pH} \mathrm{8.0)}$. Fractions enriched in $\beta-1,3$-glucanase activity were pooled and recovered after dialysis in distilled water and freeze-drying.

\section{SDS-PAGE}

A discontinuous SDS gel electrophoresis of $15 \%$ acrylamide was performed using a vertical minigel system (Bio-Rad Inc., USA) with a $0.75 \mathrm{~mm}$ thickness. The gel was prepared basically according to Laemmli (1970).

\section{Detection of $\beta$-1,3-glucanase extract from SDS- PAGE}

Detection of the $\beta$-1,3-glucanase activity in SDSPAGE was made after gel electrophoresis, according to the methodology described by Trudel and Asselin (1989). At the end of the run, the gel was carefully taken from the glass plates and incubated for $24 \mathrm{~h}$ at $37{ }^{\circ} \mathrm{C}$ with $0.1 \mathrm{~mol} \mathrm{~L}^{-1}$ sodium acetate buffer $\mathrm{pH} 5.0$ containing $1 \%$ Triton X-100 (prepared immediately before use). After incubation, the gel was washed in $0.1 \mathrm{~mol} \mathrm{~L}^{-1}$ sodium acetate, $\mathrm{pH} 5.0$, and the $\beta-1,3$-glucanase activity was immediately determined, as described in item, $\beta$-1,3-glucanase enzyme activity

\section{RESULTS}

Fig. 1 shows the scaning electron microscopy of the colleters from $S$. glaziovii found on the adaxial surface of stipules. This revealed the presence of numerous colleters with a large quantity of secretion may be seen.

F/0-70 fraction analyzed by SDS-PAGE (Fig. 2) showed that the secretion from $S$. glaziovii was a mixture of proteins with molecular masses covering a range approximately from 45 to $14 \mathrm{kDa}$ (Fig. 2 lane A). When treated with reducing agents, inter or intra-chain disulphide linkages for some of these proteins could be seen (Fig. 2 lane B).

To identify the presence of proteins in the secretion that were related to plant defense, different enzymatic assays were performed. Peroxidase and chitinase activity was not detected under the conditions assessed. Since the presence of the $\beta-1,3$-glucanase activity was observed (Table 1). The purification of a $\beta$-1,3-glucanase from S. glaziovii secretion was achieved through the utilization of ion exchange and size exclusion chromatographies. The 0/90 ammonium sulphate fraction was initially fractionated by DEAESepharose, which demonstrated the presence of two different peaks named D1 (non retained peak) 
and D2 (retained peak and eluted with $\mathrm{NaCl} 1 \mathrm{~mol}$ $\mathrm{L}^{-1}$ ) (Fig. 3A).

When analyzing the $\beta$-1,3-glucanase activity, a high $\beta$-1,3-glucanase activity in D1 peak was observed. In a subsequent purification step, a fraction containing activity (D1) was submitted to exclusion chromatography in Sephacryl S-100 and separated into two new fractions denominated $\mathrm{S} 1$ and P2 (Fig. 3B). The analyses of $\beta$-1,3-glucanase activity demonstrated its activity mainly in the $\mathrm{S} 2$ fraction, although a small proportion was found within the S1 peak. Both the fractions from Sephacryl S-100 that presented $\beta$-1,3-glucanase activity, were submitted to SDS-PAGE. Fig. 4 shows the partial purification of $\beta-1,3$-glucanase from $S$. glaziovii secretion. The $\mathrm{S} 1$ fraction from Sephacryl S-100 did not present any protein bands. The S2 fraction presented a single band of the approximately $35 \mathrm{kDa}$. This band, when submitted to enzymatic assay, showed a high specific activity for $\beta$-1,3-glucanase.

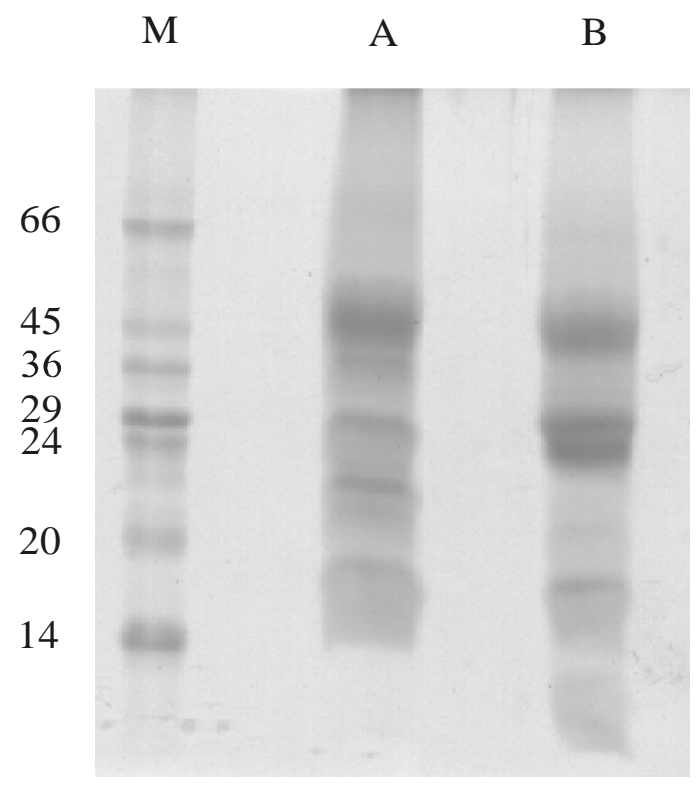

Figure 2 - Denaturing SDS-PAGE of fraction F/0-90 obtained from secretion of S. glaziovii colleters. A - Sample without treatment with $\beta$-mercaptanoethanol; B - sample treated with $\beta$-mercaptanoethanol; $\mathrm{M}$ - markers (kDa).

Table 1 - Activity of $\beta$-1,3-glucanase, chitinase and peroxidase enzymes found in the F/0-90 fraction from S. glaziovii secretion. Enzyme activities were measured in the freeze-dried secretion recovered. Results are the means of three determinations.

\begin{tabular}{l|c|c}
\hline \multicolumn{3}{c}{ Activity analysis in the crude secretion } \\
\hline \multicolumn{1}{c}{ Enzymes } & $\begin{array}{c}\text { Activity } \\
\left(\text { Units mg } \text { protein) }^{-1}\right.\end{array}$ & Standard deviation \\
\hline$\beta$-1,3-glucanase & 3.160 & 0.00972 \\
Chitinase & 0 & 0 \\
Peroxidase & 0 & 0 \\
\hline
\end{tabular}



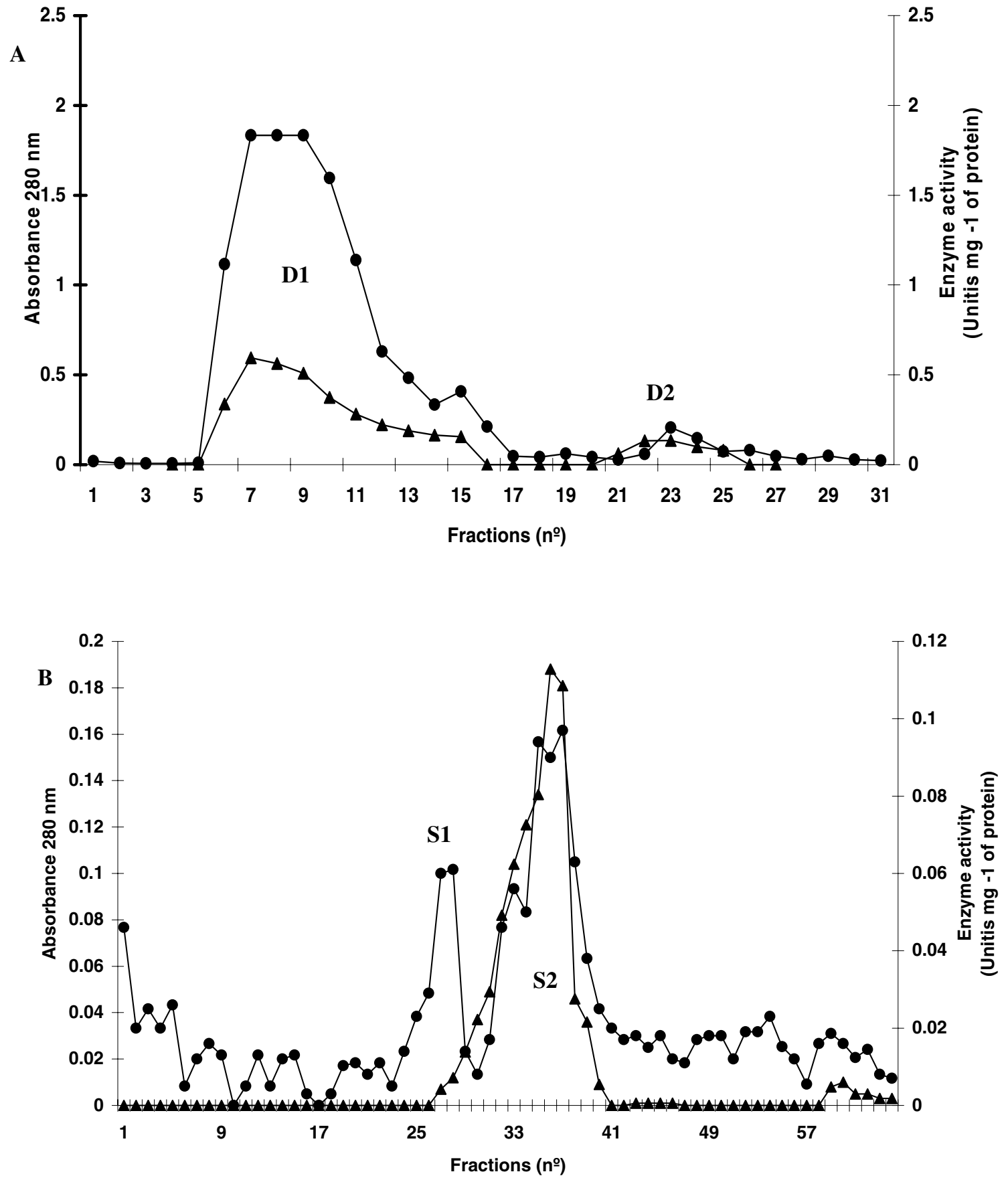

Figure 3 - A- DEAE-Sepharose chromatography of the (F/0-90). The column was equilibrated with $0.1 \mathrm{molL}^{-1}$ Tris-HCl buffer ( $\mathrm{pH} 8.0$ ) and eluted with $1 \mathrm{~mol} \mathrm{~L}^{-1} \mathrm{NaCl}$. Protein absorbance at $280 \mathrm{~nm}(\bullet)$; $\beta$-1,3-glucanase activity $(\boldsymbol{\Delta})$. B - Chromatography of the D1 fraction in the Sephacryl S-100 column. The column was equilibrated and eluted with $0.05 \mathrm{~mol} \mathrm{~L}^{-1}$ sodium acetate buffer, $\mathrm{pH} 5.0$, at a constant flow rate of $30 \mathrm{mLh}^{-1}$. Protein absorbance at $280 \mathrm{~nm}(\bullet) ; \beta$-1,3-glucanase activity $(\boldsymbol{\Delta})$. 


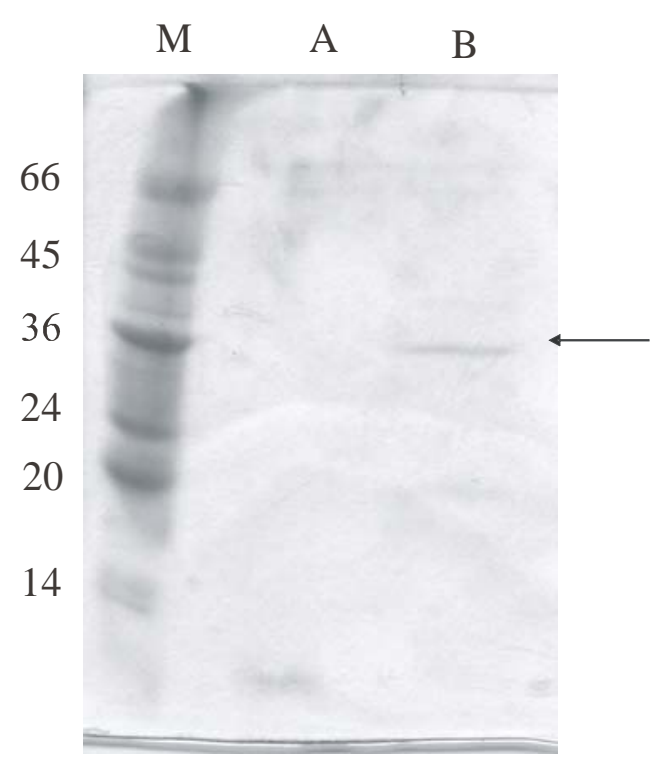

Figure 4 - SDS-PAGE, under denaturing conditions, of the fractions obtained after Sephacryl S-100 chromatography. A - S1; B - S2; M - markers (kDa).

\section{DISCUSSION}

$\beta$-1,3-glucanase has been purified from many plant species, usually by multi-step procedures employing ion exchange columns followed by gel filtration and hydrophobic interaction (Young and Pegg, 1982; Kauffmann et al., 1987; Mauch et al., 1988; Balance and Sevendsen, 1988; Vogeli et al., 1988; Kurosaki et al., 1991). In this study, the presence of a $\beta-1,3$-glucanase in the secretion of the Simira glaziovii colleter was investigated.

Similar techniques as used in this work have been used for the purification of $\beta$-1,3-glucanase in celery (Stephen and Rebecca, 1993), tomato seeds (Yukio and Hisashi, 2000), pepper stems (Young and Byung, 1997) and young barley leaves (Maria and Geoffrey, 1993).

The physical-chemical characteristics, found in $S$. glaziovii $\beta$-1,3-glucanase, were very similar to the properties of celery $\beta-1,3$-glucanase and of those of other species of plants, with a molecular mass of $35 \mathrm{kDa}$, an acidic isoelectric point (4.1) and optimum $\mathrm{pH}$ of 5.2-5.5 (Stephen and Rebecca, 1993; Young and Pegg, 1982; Kauffmann et al., 1987; Mauch et al., 1988).

Secretory structures, such as trichomes (Williams et al., 1982), nectaries (Arumugasamy et al., 1990) and salt and resin glands (Subramarian et al., 1989), in addition to being involved in pollination processes, osmorregulation and reduction of the perspiration in several organs, are also involved in the defense of the plant against herbivore and pathogen attacks (Fanh, 1987; Thomas, 1991). Detection of $\beta-1,3$-glucanase exuded in the secretion of the $S$. glaziovii colleter suggested that this structure could be related to the defense of the plant against pathogen attacks. Plants exude a variety of substances through their aerial parts, roots and germinating seeds. Many of these substances are used by the plants to create adverse conditions or may attack the pathogen directly (Beart et al., 1985; Friend, 1991).

Similarly to the secretion of $S$. glaziovii, only one soluble $\beta-1,3$-glucanase exists in celery (Stephen and Rebecca, 1993), unlike in other species of plants, where different isoforms of Chitinase and $\beta$-1,3-glucanase usually exist (Pegg and Yong, 1981; Kauffmann et al., 1987; Mauch et al., 1988; Ward et al., 1991). The detection of a $\beta-1,3-$ glucanase in the $S$. glaziovii secretion, confirmed by enzymatic assay after a SDS-PAGE suggested that the exuded protein secretion possesses a defense role. This defense role has already been showed by Robbrecht (1988), who described the biological importance of the colleter secretion in increasing the structural protection offered by the stipules and chalices to the merystematic tissues. 


\section{RESUMO}

Uma $\beta$-1,3-glucanase foi purificada a partir da secreção de Simira glaziovii, através de vários processos cromatográficos, tendo a análise do perfil protéico acompanhado de SDS-PAGE. A enzima purificada apresentou uma massa molecular estimada de $35 \mathrm{kDa}$. O pH ótimo obtido para a enzima foi de 5,2.

\section{ACKNOWLEDGEMENT}

We acknowledge the financial support from the Brazilian agencies, $\mathrm{CNPq}$ and FAPERJ, and from the Universidade Estadual do Norte FluminenseDarcy Ribeiro.

\section{REFERENCES}

Alexopoulos, C. J.; Mims, C. W. and Blackwell, W. (1996), In Introductory mycology: characteristics of fungi. $4^{\text {th }}$ ed. New York: John Wiley \& Sons. v. 2. pp. 26-60.

Arumugasamy, K.; Subramanian, R. B. and Inamdar, J. A. (1990), Struture, ontogeny and histochemistry of cyathial nectaries in euphorbia-heterophylla L. (euphorbiaceae). Acta Societatis Botanicorum Poloniae, 59, 3-8.

Ballance, G. M. and Svendsen, I. B. (1988), Purification and amino acid sequence determination of an endo- $\beta$ 1,3-glucanase from barley. Carlsberg Research Communication, 53, 411-419.

Beart, J. E.; Lilley, T. H. and Haslam, E. (1985), Plant polyphenols secondary metabolism and chemical defense: some observations. Phytochemistry, 24, 8-33.

Boller, T. (1987), In plant-microbe interactions: molecular and genetic perspectives: hydrolytic enzymes in plats disease resistance. New York: MacMillan. v. 2. pp. 385-413.

Boller, T. and Mêtraux, J. P. (1988), Extracellular localization of chitinase in cucumber. Physiology and Molecular Plant Pathology, 33, 11-16.

Bradford, M. M. (1976), A rapid sensitive method for the quantification of microgram quantities of protein utilising the principle of dye binding. Biochemistry, 72, 248-254.

Caramori, S. S.; Lima, C. S. and Fernandes, K. F. (2004), Biochemical characterization of selected plant species from Brasilian savanas. Brazilian Archives of Biology and Technology, 47, 253-259.

Chye, M. L. and Cheung, K. Y. (1995), $\beta$-1,3-glucanase is highly-expressed in laticifers of Hevea brasiliensis. Plant Molecular Biology, 29, 397-402.
Darvill, A. G. and Albersheim, P. (1984), Phytoalexins an their elicitors - a defense against microbial infection in plants. Annual Review of Plant Physiology, 35, 243-275.

Fahn, A. (1987), Extrafloral nectaries of Sambucus niger L. Annals of Botany, 60, 299-308.

Fink, W.; Liefland, M. and Mendgen, K. (1988), Chitinases and $\beta$-1,3-glucanases in the apoplastic compartment of oat leaves (Avena sativa L.). Plant Physiology, 88, 270 - 275.

Friend, J. (1991), The Biochemistry and Cell Biology of Interaction. Advances in Plant Pathology, 7, 85-129.

Gomes, V. M. and Xavier-Filho, J. (1994), Biochemical defenses of plants. Brazilian Archives of Biology and Technology, 37, 371-383.

Kauffmann, S.; Legrand, M.; Geoffroy. P. and Fritig, B. (1987), Biological function of pathogenesis-related protein: Four PR proteins of tobacco-leaves have $\beta$ 1,3-glucanase activity. EMBO Journal, 6, 3209-3212.

Klein, D. E.; Gomes, V. M.; Silva-Neto, S. J. and Cunha, M. (2004), The structure of colleters in several species of simira (Rubiaceae). Annals of Botany, 94, 733-740.

Kombrik, E.; Schröder, M. and Hahlbrock, K. (1988). Several pathogenesis-related proteins in potato are $\beta$ 1,3-glucanases and chitinases. Proceedings of the National Academy of Science USA., 85, 782-786.

Kurosaki, U.; Tokitoh, Y. and Nishi, A. (1991), Purification and characterization of wall-bound $\beta-1,3-$ glucanase in cultured carrot cells. Plant Science, 77, 21-28.

Laemmli, U. K. (1970), Cleavage of structural proteins during the assembly of the head of bacteriophague T4. Nature, 227, 680-685.

Legrand, M.; Kauffmann, S.; Geoffroy. P. and Fritig, B. (1987), Biological function of pathogenesis-related protein is chitinases. Proceedings of the National Academy of Science USA, 64, 6750-6754.

Leon, I. C.; Alpeeva, I. S.; Shubar, T. A.; Galaev, I. Y.; Csoregi, E. and Sakhar, O. V. I. Y. (2002), Purification and substrate specificity of peroxidase from sweet potato tuber. Plant Science, 663, 1111-1119.

Hrmova, M. and Fincher, G. B. (1993), Purification and properties of three (1-3)- $\beta$-D-glucanase isoenzymes from young leaves of barley (Hordeum vulgare). Biochemical Journal, 289, 453-461

Mauch, F.; Hadwiger, L. A. and Boller, T. (1988), Antifungal hydrolases in pea tissue. 1. Purification and characterization of two chitinases and $\beta-1,3-$ glucanase differentially regulated during development and in response to fungal infection. Plant Physiology, 87, 325-333.

Mauch, F. and Staehelin, L. A. (1989), Functional implications of the subcellular localization of ethylene-induce chitinase and $\beta$-1,3-glucanase in been leaves. Plant Cell, 1, 447-457. 
Molano, J.; Polacheck, I.; Durán, A. and Cabib, E. (1979), An endo-chitinase from wheat germ. Journal of Biologycal Chemistry, 254, 4901-4907.

O'Brien, M. and Colwell, R. R. (1987), A rapid test for chitinase activity that uses 4-methylumberiferyl-Nacetyl-D-glucosaminide. Applied Environmental Microbiology, 7, 1718-1720.

Oliveira, A. S.; Xavier-Filho, J. and Sales, M. P. (2003), Cysteine proteinases and cystatins. Brazilian Archives of Biology and Technology, 46, 91-104.

Pascholati, S. F. and Leite, B. (1994), Mecanismos bioquímicos de resistência às doenças. Revisão Anual de Patologia de Plantas, 2, 1-51.

Pegg, G. F. (1977), Glucanohydrolases of higher plants: A possible defense mechanism against parasitic fungi, in Cell wall Biochemistry Related to Specificity in Host Plant-Pathogen interaction. (Osio: Universitetsforiage). pp. 371-382.

Pegg, G. F. and Young, D. H. (1981), Changes in glycosidase activity and their relationship to fungal colonization during infection of tomato by Verticillium albo-atrum. Physiology and Plant Pathology, 19, 371-382.

Robbrecht, E. (1988), Tropical woody Rubiaceae. Characteristic features and progressions. Contributions to a new subfamilial classification. Opera Botanica Belgica, 1, 1-271.

Subramanian, R. B.; Murugan, V.; Mohan, J. S. S. and Inamdar, J. A. (1989), Optical microscopic studies on the structure and secretion of resin glands in some Apocynacea. Proceedings of the Indian Academy of Sciences-Plant Science, 99, 423-429.

Stephen, L. K. and Rebecca, G. (1993), Affinity purification and characterization of a $\beta$-1,3-glucanase from celery. Plant Science, 93, 31-39.

Thomas, V. (1991), Review, Structural, functional and phylogenetic aspects of the colleter. Journal of Botany, 68, 278-305.

Trudel, J. and Asselin, A. (1989), Detection of chitinase activity after polyacrylamide gel electrophoresis. Analytical Biochemistry., 178, 362-366.

Vögeli, V.; Meins, P. and Boller, T. (1988), Coordinated regulation of chitinase and $\beta$-1,3-glucanase in been leaves. Planta, 174, 364-372.

Vögeli-Lange, R.; Fründt, C.; Hart, C. M.; Beffa, R.; Nagy, F. and Meins Jr., F. (1994), Evidence for a role of $\beta$-1,3-glucanase in dicot seed germination. Plant Journal, 5, 273-278.
Ward, E. R.; Payne, G. B.; Moyer, M. B.; Williams, S. S.; Sharkey, K. C.; Beck, J. J.; Taylor, H. T.; Ahigoy, P.; Meins Jr., F. and Ryals, J. A. (1991), Differential regulation of $\beta$-1,3-glucanase messenger RNAs in response to pathogen infection. Plant Physiology, 96, 365-367.

Williams, R. F.; Metcalfe, R. A. and Gust, L. W. (1982), The genesis of form in Oleander (Nerium oleande L.). Australian Journal of Botany, 30, 677-687.

Young, D. H. and Pegg, G. F. (1982), The action of tomato and Verticillium albo-atrum glycosidases on the hyphal wall of $V$. albo-atrum. Physiology and Plant Pathology, 21, 411-423.

Young, J. K. and Byung, K. H. (1997), Isolation of a basic 34-kiloDaltons $\beta$-1,3-glucanase with inhibitory activity against Phytophthora capsici from pepper stems. Physiology and Molecular Plant Pathology, 50, 103-115.

Yun, D. J.; Bressan, R. A. and Hasegawa, P. M. (1987), Plant antifungal proteins, in: J. Janick (Ed), Horticultural Reviews, Willey, New York, 14, 39-88.

Morohashi, Y. and Matsushima, H. (2000), Development of B-1,3-glucanase activity in germinated tomato seeds. Journal of Experimental Botany, 51, 1381-1387.
Received: April 19, 2005; Revised: September 27, 2005; Accepted: August 30, 2006. 